\title{
Ergonomic Adjustments of a Website due to Changes in Preferences and Mechanisms of Information Perception by People
}

\author{
V.V. Evenko ${ }^{1}$, A.A. Puzacheva ${ }^{1}$, D.D. Belikova ${ }^{1}$ \\ v.v.evenko@gmail.com|puzachevaaa@mail.ru|diana.belikova@yandex.ru \\ ${ }^{1}$ Bryansk State Technical University, Bryansk, Russia
}

\begin{abstract}
The article discusses the significance of changes in personal preferences and user information perception mechanisms to adjust the requirements for the appearance of information providing objects. The clip thinking phenomenon is considered as one of the main sources of changing the information perception mechanism by people. The article proposes and mathematically describes an information model for assessing the main indicators of the attractiveness of an information object. A method of assessing users' personal preferences, which has been tested on the target audience of company websites, is considered. Conclusions have been made about the necessity to adjust the requirements for website ergonomics.
\end{abstract}

Keywords: perception mechanisms, website ergonomics, information model, information object, methodology, target audience.

\section{Introduction}

Every day a person perceives a large amount of various kinds of information. With the development of information technologies and means of mass communication, audiovisual media are becoming the main information carriers. This strongly affects human cognitive perception: fragmentary consciousness is growing and clip thinking is spreading [2].

One of the features of clip thinking is acute reaction to emotions and feelings, which, as a result, governs the decisionmaking process. Therefore, people with such a phenomenon of thinking are easily led and manipulated. Impact through visual media is very effective because visual images, appealing to associative links, are better remembered and longer stored in memory.

Now people have a choice and a focus solely on the functionality of an information providing object, be it a website, an advertisement or something else, is not enough to attract a wide audience [3,5].

When making a choice in favor of a particular information object, people are often guided by various criteria. Thus, an ideal information object should combine convenience, functionality, and visual appeal.

To ensure the convenience and efficiency of user interaction with an information object, there are rules of ergonomics [7] and usability [9]. But often, an information object which is very good from a functional point of view does not receive adequate support from users. Therefore, it is important to understand how meaningful the changes in user information perception and preferences are and, taking them into account, whether it is necessary to periodically adjust the requirements for ergonomics.

Before answering the main research question, it is necessary to assess the attractiveness of a particular information object from the point of view of the target audience. Fig. 1 represents an information model for evaluating the main indicators that determine attractiveness of an information object.

\section{Information Model Description}

Suppose there is some target audience $X$ and information object $Y$. It is necessary to determine the attractiveness of information object $Y$ taking into account personal preferences of audience $X$.

Two sets enter the system: $V$ (disturbance action) and $U$ (control action).

$$
V=\left\{v_{1}, \ldots, v_{i}, \ldots, v_{r}\right\},
$$

where $V$ is a set of characteristics of representatives of target audience $X$,

$v_{i}$ is a set of characteristics of respondent $i$,

$r$ is the number of respondents.

$$
\begin{gathered}
v_{i}=\{\{A\},\{B\},\{C\}\}, i=1 \ldots r, \\
A=\left\{a_{1}, \ldots, a_{n}\right\}, n \geq 1,
\end{gathered}
$$

where $A$ is a subset containing respondents' physical characteristics.

$$
B=\left\{b_{1}, \ldots, b_{m}\right\}, m \geq 1,
$$

where $B$ is a subset containing respondents' psycho-emotional characteristics.

$$
C=\left\{c_{1}, \ldots, c_{s}\right\}, s \geq 1,
$$

where $C$ is a subset containing respondents' intellectual characteristics.

$$
U=\{\{D\},\{T\}\},
$$

where $U$ is a set describing the calculating and averaging method as well as the information object type,

$T=\{t\}$ is a one-element subset describing the type of information object $Y$.

$$
D=\left\{d_{1}, \ldots, d_{k}\right\}, k=n+m+s,
$$

where $D$ is a subset describing the method of calculating and averaging respondents' characteristics.

Using function $P$, characteristics of the average representative of the target audience are determined:

$$
P(V, D)=M \text {, }
$$

where $M$ is a set containing characteristics of respondents' average representative.

Using function $H$, methods for evaluating attractiveness are determined in accordance with the type of an information resource:

$\mathrm{H}(\mathrm{V}, \mathrm{T})=\{\{\mathrm{fm}\},\{\mathrm{cm}\},\{\mathrm{dm}\}\}$,
where $f m=\left\{f m_{1}, \ldots, f m_{n}\right\}$ is functionality evaluation

$\mathrm{cm}=\left\{\mathrm{cm}_{1}, \ldots, \mathrm{cm}_{n}\right\}$ is usability evaluation methods,

$d m=\left\{d m_{1}, \ldots, d m_{n}\right\}$ is design evaluation methods.

This process is obligatory for execution, since, for example, attractiveness evaluation of an advertisement and a website interface are conducted using different methods.

Using methods $\mathrm{fm}_{1}, \ldots, \mathrm{fm}_{n}$, we obtain afm $_{1 i}, \ldots$, afm $\mathrm{fm}_{\mathrm{i}}$ - functionality estimates for respondent $i$, where $i=1, \ldots, r$.

The usability $(\mathrm{acm})$ and design $(\mathrm{adm})$ estimates are defined similarly.

Total functionality evaluation is

$$
\text { safm }=\left\{\sum_{1}^{n} a f m_{1}, \ldots, \sum_{1}^{n} a f m_{r}\right\} .
$$

Total usability evaluation is

Total design evaluation is

$$
\text { sacm }=\left\{\sum_{1}^{n} a c m_{1}, \ldots, \sum_{1}^{n} a c m_{r}\right\} .
$$

$$
\operatorname{sadm}=\left\{\sum_{1}^{n} a d m_{1}, \ldots, \sum_{1}^{n} a d m_{r}\right\} .
$$




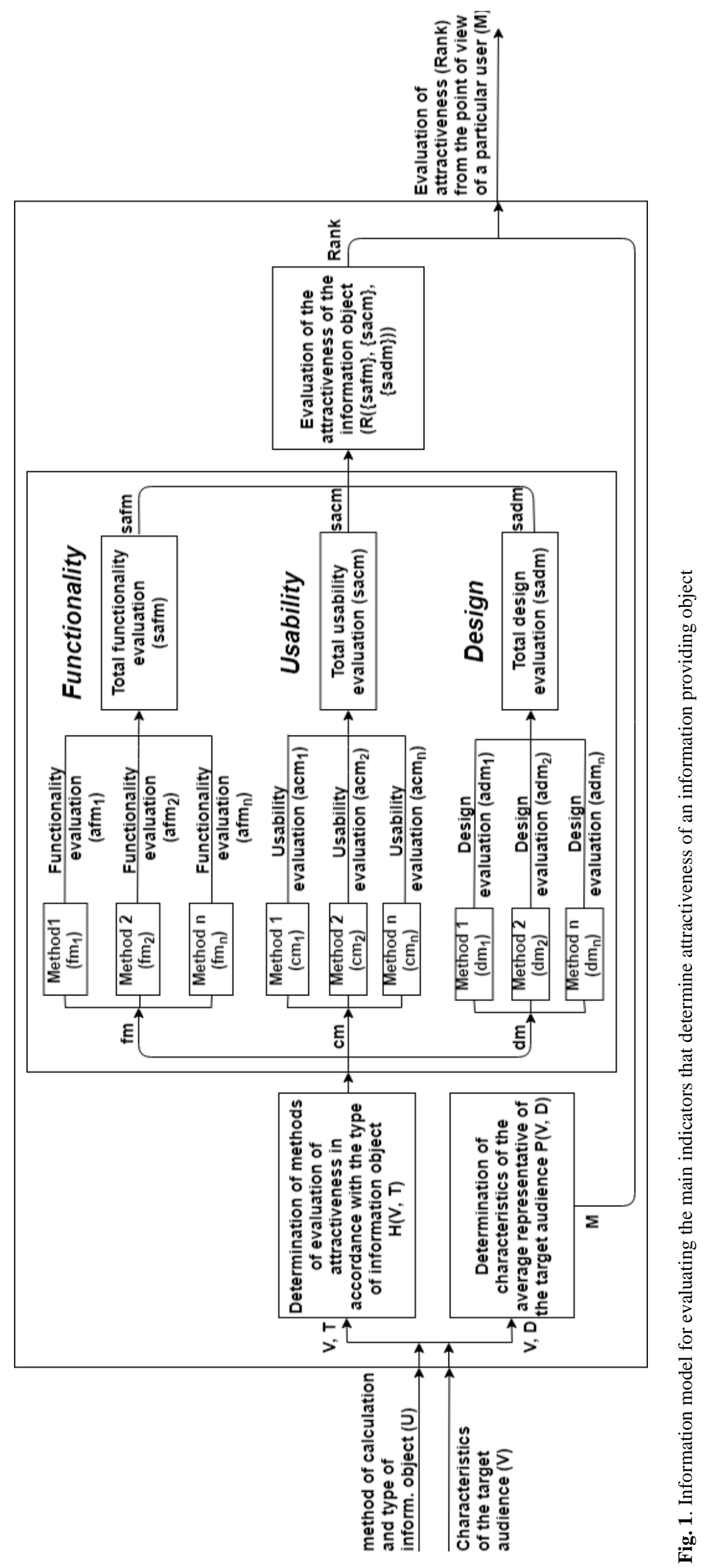


The attractiveness evaluation of information object $Y$ is determined as follows:

$$
R(\{\mathrm{safm}\},\{\mathrm{sacm}\},\{\mathrm{sadm}\}=\text { Rank. }
$$

At the input, we obtain attractiveness evaluation of information object Rank from the point of view of a user with characteristics $M$.

\section{Implementation Areas of the Information Model}

The information model can be used to evaluate the attractiveness of websites, advertisements, mobile application interfaces, etc. taking into account target audience representatives' personal preferences.

In particular, the information model can be used to evaluate the attractiveness of company websites.

In 2017, a study was conducted; its results indicated that companies having no website of their own lost approximately $25 \%$ of customers.

A website is organization's image. It acts as a company office where a client or partner can learn information about his future business partner. For successful activity in the market, the company should have a convenient and informative website $[4,6]$, which will facilitate clients' transfer from the category of "potential" to the category of "real" ones. Therefore, it is important to follow the changes in preferences and user information perception mechanisms and promptly adapt to them.
"The most meaningful way to differentiate your company from your competitors, the best way to put distance between you and the crowd is to do an outstanding job with information" (Bill Gates).

There are various methods for evaluating the attractiveness of company websites. Let us consider an example of a methodology focused on the study of users' personal preferences proposed by the authors on the basis of the information model described above.

\section{Personal Preference Methodology}

To study user preferences, a research was conducted on four age focus groups: $18-30$ years old, $31-45$ years old, 46-60 years old, from 60 years old and older.

During the first stage of the experiment, participants were offered four different texts of the same size, for which different types of fonts were used. The research goal was to investigate the dependence of information acquisition rate on the type of font and to determine the most preferred font for users.

The texts were presented in the following fonts:

1. Text 1 - Trebuchet MS;

2. Text 2 -Arial;

3. Text 3-TimesNewRoman;

4. Text 4-Cambria.

Table 1 presents a sample of the respondents' answers.

User preference research

\begin{tabular}{|c|c|c|c|c|c|c|c|c|c|c|c|}
\hline \multirow{3}{*}{ № } & \multirow{3}{*}{ Age } & \multirow{2}{*}{\multicolumn{4}{|c|}{ Reading time, min. }} & \multirow{2}{*}{\multicolumn{4}{|c|}{$\begin{array}{c}\text { Information acquisition rate, } \\
\% \\
\text { Texts }\end{array}$}} & \multirow{3}{*}{$\begin{array}{l}\text { Psychological } \\
\text { type }\end{array}$} & \multirow{3}{*}{$\begin{array}{l}\text { The most pleasant } \\
\text { for perception text }\end{array}$} \\
\hline & & & & & & & & & & & \\
\hline & & 1 & 2 & 3 & 4 & 1 & 2 & 3 & 4 & & \\
\hline 1 & 19 & 1,46 & 2,26 & 2,24 & 2,50 & 50 & 75 & 50 & 100 & Choleric & Text 2 \\
\hline 2 & 20 & 3,14 & 4,25 & 4,22 & 3,50 & 100 & 100 & 75 & 80 & $\begin{array}{l}\text { Choleric- } \\
\text { sanguine }\end{array}$ & Text 2 \\
\hline 3 & 21 & 2,56 & 4,11 & 6,32 & 4,11 & 25 & 50 & 50 & 25 & Sanguine & Text 2 \\
\hline 4 & 18 & 2,00 & 3,21 & 3,25 & 3,01 & 25 & 25 & 75 & 50 & Choleric & Text 3 \\
\hline 5 & 18 & 3,44 & 4,26 & 4,18 & 3,00 & 80 & 100 & 80 & 75 & Sanguine & Text 3 \\
\hline 6 & 18 & 2,31 & 3,19 & 3,58 & 3,34 & 25 & 75 & 50 & 50 & Sanguine & Text 2 \\
\hline 7 & 18 & 2,42 & 2,51 & 3,14 & 3,19 & 20 & 50 & 25 & 50 & Choleric & Text 4 \\
\hline 8 & 19 & 3,00 & 4,28 & 4,40 & 4,56 & 30 & 50 & 25 & 75 & Melancholic & Text 4 \\
\hline 9 & 19 & 3,06 & 4,29 & 4,53 & 4,29 & 25 & 50 & 75 & 75 & Choleric & Text 3 \\
\hline 10 & 35 & 4,00 & 3,42 & 4,05 & 3,59 & 75 & 75 & 50 & 50 & Melancholic & Text 1 \\
\hline
\end{tabular}

After the first stage of the experiment, it was concluded that the rate of information acquisition and visual simplicity of text perception were directly dependent. Thus, most of the subjects during the control testing stated that Text 2 was the most readable. Respondents noted that when reading Text 1 , they experienced eyestrain.

It should be noted that such medical indicators as heart rate and pressure were also monitored during the study. The research was conducted over a relatively short period of time and all participants did not experience significant changes in either of the indicators. This suggests that the type and convenience of a font do not have any direct effect on the level of respondent's excitement (then the heart rate would have increased) or on his general well-being.

At the second stage, background color effect on the user's perception of information was studied [1], as well as the most pleasant colors for him.

At the end of this stage, it was revealed that the most readable combination is almost any combination "dark font - light background". So, speaking of a straight text, for example, an article or report, the classic black and white scheme should be used. However, if a company wants to place a banner ad on its website or to attract customer's attention to some important information, it can use, for example, the following colors: black font - yellow background and blue font - white background.

All respondents noted that the combination of red font on a green background makes the text almost unreadable, especially if it is used for an article design. People in the focus groups claimed that by the end of reading the article designed in this way they had eyestrain and irritation. It is also worth noting that part of the respondents did not finish reading the article, because they were uncomfortable. This is an example of how an incorrectly chosen combination of colors [8] can lead to the loss of customers and lost profits.

Exploring specific target audience under given conditions makes it possible to evaluate the need to go beyond the harmonious combinations on the color wheel.

The described methodology is oriented toward the information model and takes into account various approaches to the assessment of personal preferences (functionality, usability and design). The resulting 
estimates ultimately form an integral evaluation of users of company sites' personal preferences. Final evaluation allows for the conclusion about viability of a website improvement procedure and helps to determine key directions of changes.

\section{Conclusion}

The paper has substantiated the relevance of the study; it has proposed and mathematically described an information model for evaluating the main indicators of information object attractiveness. A method of assessing users' personal preferences, which has been tested on the target audience of companies' websites, has been considered and a number of conclusions have been made. For example, that in the conditions of wide spreading clip thinking, the ratio of human perception of textual and graphical information changes. Graphic information and animation used to act as distracting elements, but now a person's attention is focused on them. Besides, negative and provocative content is often of the greatest public interest as it is able to awaken a wide range of feelings and emotions in a modern person, living in relative peace and security.

The developed information model allows adjusting the requirements for standards and rules of constructing information objects taking into consideration their types and preferences of the target audience. Skillful and relevant adjustment of requirements can increase the demand for and awareness of an information object.

\section{References}

[1] Averchenkov V.I. Spasennikov V.V., Rytov M.Y,, Kondratenko S.V., Kuzmenko A.A. (2017) Methodology of evaluation of operators activities in man-machine systems with color estimates. Proceedings of the International Conference on Industrial Engineering, Applications and Manufacturing (ICIEAM) (St. Petersburg, Russia, May 1619, 2017), IEEE Xplore Digital Library. doi: 10.1109/ICIEAM.2017.8076141

[2] Berezovskaya I.P. (2015) [Problem of Methodological Substantiation of the Concept "Clip Thinking"]. St. Petersburg State Polytechnical University Journal. Humanities and Social Sciences, no. 2 (220), pp. 133-138. (in Russian). doi: 10.5862/JHSS.220.15

[3] Bogomolov S.A., Spasennikov V.V. (2018) Problemy standartizacii jergonomicheskih trebovanij $\mathrm{v}$ processe sozdanija novyh sistem, izdelij i innovacionnyh tehnologij [Ergonomic Requirements Standardization Problems During Formation of New Systems, Products And Innovation Technologies]. Bulletin of Bryansk State Technical University, no. 1 (62), pp. 73-84. (in Russian). doi: 10.12737/article 5a795ffc64d127.49426895

[4] Dergachyov K.V. (2015) Obespechenie jergonomichnosti pol'zovatel'skogo interfejsa pri proektirovanii veb-sajtov [Ensuring of Interface Usability in Websites Design]. Proceedings of the Innovation Methods and Models in Economic Psychology, Ergonomics and Industrial Management: All-Russian Scientific and Practical Conference with International Participation (Bryansk, Russia, October 25-26, 2015), Bryansk State Technical University, pp. 196-199. (in Russian).

[5] Dergachyov K.V., Spasennikov V.V., Kondratenko S.V. (2017) Jergonomicheskoe obespechenie razrabotki dizajna logotipov [Ergonomic Support for Development of Logo Design]. Proceedings of the Academy of Technical Aesthetics and Design, no. 1, pp. 41-46. (in Russian).

[6] Evenko V.V., Shakhovskaya A.A. (2014) Metodika ocenki jergonomicheskoj sbalansirovannosti korporativnogo sajta promyshlennogo predprijatija
[Methods for Evaluation of Ergonomic Balance of Corporative Website of Industrial Enterprise]. Bulletin of Bryansk State Technical University, no. 2 (42), pp. 107113. (in Russian).

[7] Munipov V.M. (2001) Jergonomika [Ergonomics]. Moscow: Logos. (in Russian).

[8] Kak pravil'no vybrat' cvetovuju shemu dlja sajta [How to Choose the Color Scheme for a Website Correctly]. Available at: https://www.internet-technologies.ru/articles /kak-pravilno-vybrat-cvetovuyu-shemu-dlya-sayta.html (accessed 30 June 2019) (in Russian).

[9] Chto takoe juzabiliti? [What Does Usability Mean?]. Available at: https://usabilitylab.ru/blog/chto-takoeyuzabiliti/ (accessed 30 June 2019) (in Russian). 